\title{
Analyzing the governance of security: Jurisdiction and scale
}

\author{
Mariana Valverde
}

\begin{abstract}
Two related arguments are developed in this paper. First of all, it is shown that theoretical work on the governance of security could benefit a great deal from the current literature on law and geography and law and space. Given that security projects tend to presuppose a particular scale (an institution; a neighbourhood, a city, etc.), security theorists would benefit from engaging with the critical work on 'scale' that outlines the various political effects of choices of scale (in both cartographic and metaphorical deployments of 'scale'). Secondly, this article also argues that the analytical resources of 'scale' should be supplemented by insights derived from analyzing the workings of jurisdiction. Jurisdiction does not merely distinguish who governs: it also distributes governance in terms of governing capacities, objects of governance, and modes of governance. Taking jurisdiction for granted (for example, by assuming that immigration is state-level but garbage disposal is municipal) thus naturalizes and blackboxes differences in modes of governance that could benefit from being closely questioned. Using the 'police power of the state', with its typically urban scale, as the main example, the article shows that unpacking 'jurisdiction' can enrich the legal geographers'existing critiques of scale.
\end{abstract}

Keywords: jurisdiction; scale; legal geography; security

\section{Security and scales of governance}

Like 'democracy' and 'liberty', 'security' is a keyword of political thought blessed with a very rich range of meanings. Semantically and symbolically rich terms are often regarded by scholars as 'confused' or 'fuzzy', as problem terms in need of rigorous conceptual analysis. No doubt an analytic philosopher could take 'security' and try to 'clarify' it by filing off the rough and fuzzy edges. This purely conceptual task would perhaps clear up some misunderstandings: but it would not help us to comprehend and analyze the rich variety of governance processes that are effected through the array of uncoordinated ideals, norms, practices, and habits that 'security' enables and that in turn constitute the meanings of the term.

To analyze terms that are admittedly fuzzy and polysemic but that do a great deal of work precisely through their capaciousness, it is more useful to take a NietzscheanFoucaultian perspective, since from that perspective, the task of the scholar is less to clarify concepts and impose rigour than to provide new insights into how governance actually happens. In that light, the ambiguity of 'security' appears less as a problem and more as a resource.

One way of carrying out a genealogical (rather than a conceptual) analysis would be to undertake a thorough history of security thinking and security practices - a monumental task. But if we aim more modestly at shedding light on a single dimension of the variety of governance projects that have been carried out under the banner of what we might call, 
after Jonathan Simon's 'governing through crime', governing through security (cf. Simon 2007, Loader 2007, Wood 2007), one useful place to begin is the question of scale.

Scale features prominently in much contemporary social theory, and not only in critical geography; but neither the literal, cartographical meaning of 'scale' nor its numerous metaphorical uses have been much used in legal and criminological thinking. This article aims to show that we can sharpen the analytic tools used to document and analyze security problematics by reflecting on the fact that security processes - like the risks that various security projects are designed to manage - always operate either wholly or paradigmatically at a certain scale.

Some risks are thought of as essentially global, others as national, and others yet as local: these shifts in scale are incorporated, usually without much discussion, into security strategies. By the same token, scholarly analyses of security problematics also tend to take up, often unthinkingly, a certain scale, such that there is a homological relation between the problem being analyzed and the approach used. Thus, in crime prevention, 'security' is taken as a condition characterizing individuals, buildings, or neighbourhoods; this implicit theory about the scale with which one visualizes security (in the sense of crime prevention) is embodied in the scale of the 'before and after' drawings and photographs typically accompanying crime prevention advice. By contrast, political and legal theory habitually privilege the scale of the nation-state: in discussions about whether antiterrorism laws err on the side of Hobbesian sovereignty one would not expect to find illustrations featuring a city block or a shopping mall. Political and legal theory work almost wholly with two scales only, the national and the transnational/global. More generally, the various approaches used by scholars to analyze security projects and security problems also tend to take a particular scale for granted. Hence, this article seeks to clarify not 'the concept of security' but rather the process by which both authorities governing security processes and scholarly analysts tend to take up a certain scale without reflecting on the way in which the choice of scale affects governance.

This article is not wholly critical, however. I will also consider how certain intellectual resources that are embedded in legal and regulatory practices might help us in the work of becoming more critically self-aware about the political (in the broadest sense) effects of choices of scale. The governance tradition that is associated with $18^{\text {th }}$ century 'police science', and with the American doctrine of 'the police power of the state', will be our main example of how governing practices can be mined, as it were, to further theoretical work in socio-legal studies. The regulatory and preventive work done under the banner of police power and police regulations embodies (and constitutes) a gaze that, in sharp contrast to the top-down, expert-driven gaze that James Scott famously baptized as 'seeing like a state' (Scott 1998), governs differently in part because its scale is paradigmatically local.

In practice, institutions are not bound by the paradigmatic scale of governance that corresponds to their location in the governmental scheme of things. Cities can and do 'see like a state' on many occasions - e.g. municipal public health inspection - and states too can 'see like a city'. Even more complicatedly, one and the same official can use different gazes at different times or even at the same time - as seen in empirical studies of regulatory officials' work, such as Keith Hawkins' exhaustive study of occupational safety regulation in the UK (Hawkins 2002, Levi and Valverde 2001). But for the purpose of reflecting on analytical tools it is useful to distinguish power/knowledge moves that are typically associated with the municipal scale of governance from the better-known, topdown, rationalizing, abstraction-driven mechanisms documented by James Scott and other scholars of modernizing governance projects (e.g. Mitchell 2002, Poovey 1998). To 
put it very simply (too simply, perhaps), seeing like a city is not the same thing as seeing like a small state.

Before getting into the substance of the 'seeing like a city' argument, however, we need to ask: what is 'scale' anyway? That the choice of scale used in making actual maps always has certain political effects is by now well known, thanks to the work of critical geography. But what is less clear is how scale works within forms of governance that are spatialized, either literally or metaphorically, but are not cartographic.

In a pioneering article Boaventura de Sousa Santos demonstrated that critical geography's insights about the politics of scale could easily be applied to the study of legal governance, since law too is fundamentally a mapping exercise. And just as different scales of maps govern differently, with the actual or potential conflicts amongst them being rendered invisible by the fact that a map's scale appears as a politically neutral technical choice, so too the variety of legal systems that converge upon and help to map a single space are arranged in some order through the fact that the different legal systems tend to operate at different scales, and thus do not conflict too directly. "Local law is a largescale legality. Nation-state law is a medium-scale legality. World law is a small-scale legality ... the different forms of law create different legal objects upon the same social objects. They use different criteria to determine the meaningful details ..." (de Sousa Santos 1987,287$)$ The constant interactions among different legal orders, each of which has its own scope, its own logic, and its own criteria for what is to be governed, as well as its own rules for how to govern make up the process that de Sousa Santos calls 'interlegality' (by analogy with 'intertextuality', one assumes). As he points out, the fact that differences in law's scales appear as neutral technical matters on a par with a mapmaker's choice of cartographic scale means that the different, quite heterogeneous modes of governance carried out by different legal assemblages appear to coexist without a great deal of overt conflict, without the heterogeneity and incommensurability that characterize interlegality leading to serious questions about the real meaning of the apparently singular mechanism of 'the rule of law'. Law's scales file down the contradictions, since legal powers and legal knowledges appear to us as always already distinguished by scale - so that, for example, we do not expect international law be coordinated or harmonized with local law.

Santos' pioneering argument was fruitfully continued in the work of legal geography scholars such as Richard Ford and Nicholas Blomley (Blomley 1994, Blomley and Bakan 1992, Cooper 1998, Ford 1999). This work uses the intellectual resources of critical geography (and other theorizations of the politics of space, e.g. Lefebvre 1991) to advance legal studies' critical edge. This literature has proven extremely fruitful over the past decade or so. Nevertheless, the application of critical geography insights to law has limits due to the unidirectional character of the interdisciplinary borrowing. Legal geography like critical legal studies generally - tends to examine only how legal analyses can benefit from the resources of critical social thought, without considering whether legality/interlegality (the practices, that is, not the 'concepts') might also be a source of inspiration for social theory.

Here, instead of taking it for granted that the task of critical socio-legal scholars is always to rescue legal scholarship from the slumbers of doctrinalism by means of deploying the latest in social theory (including geography), we will ask whether social and po- 
litical theory - in this case, theories of the governance of security - can benefit by mining the intellectual resources contained not so much in legal doctrine as in legal practice. ${ }^{1}$ Any governing practice is richer than its professional school, textbook representation, and law, as a particularly ancient and rich governing practice, contains much material that can be used to sharpen the analytic tools used to study the governance of security. I will begin the process of using legal resources to further theory by showing that when thinking about the issue of scales of governance it is useful to draw on the ancient legal concept of 'jurisdiction'.

\section{Jurisdiction and governance}

As is well known even outside of legal circles, jurisdiction often refers to territorial divides: Ontario versus Quebec, France versus Europe, Russian polar waters versus international waters. Jurisdiction, however, distinguishes more than territories. It differentiates three other key dimensions of governance:

(1) governing capacities (e.g. only the federal government can pass criminal statutes)

(2) specified objects (e.g. potholes are municipal, oil and gas are provincial, aboriginal reserves are federal), and, most importantly,

(3) modes of governance (e.g. city inspectors impose fines but cannot arrest and detain individuals).

Governing projects are thus differentiated from one another, and kept from overtly clashing, by the waving of the seemingly pre-theoretical wand of 'jurisdiction', which instantly sorts governance processes, knowledges and powers into their proper slots as if by magic.

The work performed by and through 'jurisdiction' is not at all hidden, but it is, paradoxically, usually invisible. At the level of civic life, we can find out whom to phone about $\mathrm{X}$ or $\mathrm{Y}$ issue and thus come to feel that we 'know the system'. And if we go to law school or study political science we may earn something about the historical origins of some divisions of powers. But neither the practical knowledge of jurisdiction that citizens gain as they engage with governmental processes nor the textbook knowledge about which level of government does what shed any light on the process by which jurisdiction itself - rather than the specific, substantive legal doctrines deployed by courts in adjudicating jurisdiction cases - acts to perform an ethnomethodological miracle by which incommensurable processes, or processes with incommensurable logics, are kept from clashing by being assigned to different authorities (cf. Espeland 1998).

In other words: legal discourse on jurisdiction, as well as politicians' discussions about reallocating powers and competences, take place in the language of 'who does what'. Concentrating only on the who and the what of governance effectively (and silently) blackboxes the question of mode of governance - the 'how'. Feeling that we know how the system works when we know which office to call, or when we can tell our students that criminal law is federal in Canada but state-level in the US, we are prevented from asking: If potholes are municipal and coal mines are provincial, is that simply a matter of who governs what, or is it also a matter of how they are governed? What would happen if, for example, criminal law matters were governed as if criminal law were local?

1 In this attempt to reverse the flow of critical legal thought I am inspired by Annelise Riles, especially "Taking on the technicalities: a new agenda for the cultural study of law" (Riles 2005). 
Would different rationalities and technologies of governance suddenly seem appropriate? And, going in the opposite direction, what would happen to the public infrastructure deficits of North American cities, if garbage disposal, homelessness and public transit were regarded as questions of national biopolitical security?

It is important to underline that it is not the aim of this article to normatively argue that one scale is somehow more appropriate for governing and theorizing security than another. Jane Jacobs and subsequent advocates of the new urbanism made their fame and fortune by taking on the modernizing, large-scope projects promoted by mid-twentieth century experts of urban wellbeing; but, as Iris Young among others has pointed out, privileging 'the community' has its own perils (Young 2002, 228-236). Put differently, privileging a mythologized middle-class downtown street and taking the scale of Jane Jacobs' „street“ (which in practice is only one block or at most two, never a long street that crosses neighbourhoods) may serve to show up the aesthetic and social deficiencies of highway-driven modernist planning, but the scale of 'the sidewalk' has its limitations and biases too, as shown in Mitchell Duneier's ethnography of Greenwich Village street vendors (Duneier 1999). I thus avoid 'taking sides' or engaging in normative arguments about which scale is somehow superior. After all, 'seeing like a state' may have brought us many disasters (as documented by James Scott and countless others), but in respect to certain situations - e.g. climate change - the Jane Jacobs perspective is worse than useless. And 'the street' and 'the sidewalk' recently mythologized by the new urbanism embodies a scale that privileges middle-class culture vultures who can enjoy the spectacle of urban diversity but can retreat to a well-appointed loft (Zukin 1988). Instead of engaging in abstract battles about which scale is somehow best, I seek here only to promote a greater reflexive self-awareness about the implications of falling into certain 'scale' habits when analyzing the governance of security.

Having dealt with the content of 'scale', a final preliminary (or not so preliminary) matter concerns the question, which of the many meanings of 'security' is relevant here. If we are undertaking to think about the large variety of projects motivated by or justified by 'security', it makes most sense to take 'security' in the very broad sense pursued by Foucault in his lectures on 'governmentality' - where he distinguished the narrower, more immediate concern for the state's own security, which he calls sûreté, from securité in the sense of social security, citizen security, and collective prosperity and welfare as such (Foucault 2005). Hobbes theorized sûreté, and could not have envisioned any other security project. It is only with the emergence of 'population' (as distinct from the king's subjects) in the late eighteenth century that it becomes possible to envision the state's role as ensuring economic and biopolitical security through governing processes in which the security of the state itself is (at least in theory) coterminous with the welfare of the population.

\section{Security at the local level: the police power}

Now, questions of security in this larger and more future-oriented sense have tended to be analyzed as if state powers and state knowledges were naturally the focus of the analysis. Seeing like a state, James Scott's highly influential analysis of the reshaping of natural and human relations through expert-driven modernization projects, tends to assume that the relevant scale for the study of modern political relations is the scale of the state even though Scott includes Le Corbusier's architectural dreams alongside state projects, and is in general careful to avoid positing a fixed link between a particular gaze and a 
particular governing authority or body of personnel (Scott 1998). On its part, Foucault's own work on technologies of correction and disciplinary power, while also avoiding privileging the state as an analytic category, nevertheless ends up privileging the scale of the nation-state, if only because in France prison systems, military training, and public education were and still are controlled from Paris (Foucault 1979).

Local relations of security - and to reiterate, I am using 'security' here in Foucault's sense, that is, as the future-oriented management of risks that affect both state and citizens (Valverde 2007) - are not simply smaller, or even more informal, versions of statelevel relations. If we pay attention to important traditions of governance, particularly those that arose from or were retroactively justified under the banner of the police power, some sense of the qualitatively distinct character of security governance at the local level can be gained.

Over the past five or so years I have been involved in an informal research network concerned to document and theorize police knowledges and police powers, in the $18^{\text {th }}$ century sense of 'police', developed in the German tradition of Polizeiwissenschaft (Dubber and Valverde 2006, Dubber and Valverde 2008). In one of the two volumes to which this project gave rise, Markus Dubber and I argued that the largely regulatory and preventive governance that has as its most legally visible manifestation the American doctrine of 'the police power of the state' is an unusually flexible, even fluid form of power/knowledge that works in a qualitatively different manner than either 'high' law or modern expert disciplinary projects. The polymorphous flexibility that characterizes the largely local gaze of police regulations (which is what I earlier called 'seeing like a city') is rooted in two key features:

a) Police as a 'hinge' between the two key temporalities of governance. Police rationalities and technologies constitute, together, a kind of hinge linking, without mixing, the two central temporalities of legal-political governance of modern states: prevention and punishment, future and past, risk management and law enforcement. Sometimes these two temporalities are assigned to different agencies, or to different units within the same agency (e.g. a police department will separate out crime prevention work from detective work). In this type of situation it is more difficult to see how the 'temporal hinge' of police powers/knowledges facilitates the flexible governance of security and order problems, since the flexibility is mainly located at the point (somewhere up the management ladder) at which a decision is made about whether, say, a residential break-in warrants criminal investigation or merely a visit from the friendly prevention officer. But in many cases the two types of temporalities are available to one and the same governance unit (cf. Hawkins 2002). In many legal assemblages, some offences pre-defined as serious are immediately directed into the punishment stream (think of plagiarism policies), whereas a large range of offences can be handled either by means of future-oriented education and prevention or through past-oriented punishment. Which leads to the issue of discretion.

b) Police and the inevitability of discretion. As Paolo Napoli's recent genealogy of French police powers and institutions shows, le droit de police is different both in content and in form from le droit de justice. Le droit de police targets specific, typically local, ever-changing situations (typically, situations of disorder rather than crime) that require tailor-made solutions or risk-management strategies, rather than the application of fixed laws. For that reason, le droit de police - or what US law calls the law of the police power of the state - is highly discretionary, to the point that, as American legal dictionaries always remark, it is impossible to define it or even to enumerate all its components. The form of this power corresponds to a particular form of knowledge: namely, a quasiAristotelian phronesis, a practical wisdom that consists in the ability to decide, in each 
instance, which measure will best promote prosperity, order, and salus populi (welfare), without being bound by the general, rational, coordinated principles and rules of le droit de justice (Napoli 2003; see also Foucault, 2005).

As Napoli's exhaustive study of the rise of police mechanisms in France shows, the kind of governance authorized by 'le droit de police' is paradigmatically local. And it is possible to specify the scale of police regulation further by reflecting on the fact that in European history, the problems for which police regulations were designed to remedy were largely problems associated not only with the local but with urbanization. (The slippage between 'local' and 'urban' that theorists of the global-local relation fall into, incidentally, is one indication of the perils of relying too exclusively on the cartographic notion of scale rather than using additional qualitative distinctions.) It is not an accident that when Adam Smith, in his lectures on jurisprudence and police, wanted to distinguish high jurisprudence from police affairs - which he thought of as lowly and unimportant, perhaps because of their association with the urban/local scale - he mentioned trash disposal and street cleaning as examples of police regulation: „Police is the second general division of jurisprudence. The name is French [i.e., alien to the common law], and is originally derived from the Greek politeia, which properly signified the policy of civil government, but now it only means the regulation of the inferior parts of government, viz. cleanliness, security, and cheapness or plenty. The two former, to wit, the proper method of carrying dirt from the streets, and the execution of justice, are too mean to be considered in a general discourse of this kind." (Smith 1896 [1763], 154)

Police regulations, from Renaissance sumptuary laws (Hunt 1996), through nineteenth century ordinances exiling fireworks factories and slaughterhouses to outer areas, to contemporary zoning bylaws, are not only municipal, but are prototypically urban. In other words, the problems and risks governed by these regulations are typically associated with urbanization, even if many studies of police power and police regulations fail to comment on the characteristic scale of police regulation (e.g. Novak 1996, Dubber 2005).

Urbanization processes gave rise to certain risks that were seen as requiring a particular form of legal control that differed, qualitatively, from 'high' law. There was an existing legal machinery (including nuisance laws and local rules, vagrancy statutes, and a few other tools, such as requiring drinking establishments to be licences). But the existing machinery, targeting mainly problem people and places after the fact, did not facilitate the kind of future-oriented, preventive governance that $19^{\text {th }}$ century urban reformers felt was necessary. Some of the future-oriented governance of risks was entrusted to 'seeing like a state' agencies that worked locally (such as public health inspectors). But many urban disorder risks were regarded as requiring the kind of ad hoc measures that are difficult to fit into a 'high' law system of jurisprudence. A high level of discretion and variability, at the level of rule-making as well as the level of enforcement, characterize police regulations, and more generally police-style governance.

The discretion and flexibility characteristic of police governance is closely linked to the 'patriarchal' justifications for police power that were explicitly articulated by Blackstone and continue to be invoked in today's appellate courts (Dubber 2005). In today's police regulations, municipalities are empowered to make ad hoc decisions about where subdivisions can be built, where factories will or will not be allowed, where advertisers can rent billboard space, and so forth, and are rarely required to provide some kind of overall rational plan in the 'seeing like a state' tradition. Great principles are not regarded as necessary. And not surprisingly given the low level of attention given to principles, neither are individual rights very important. Police regulations are all about making distinctions among activities, among businesses, among urban spaces, and even among per- 
sons (though more indirectly now than in former times), and so equality arguments and constitutional law generally tend to have very little 'bite' when deployed against the powers that have traditionally been used to organize urban space and minimize or prevent disorder.

The logic of police regulation is thus at odds with other, more visible legal logics (e.g. the principles of penal law that undergird the rights of the criminally accused). Municipalities are not required to treat businesses or real estate categories equally. Occasionally they may have to justify some regulations that clash with the logics of 'higher' law - as when, in the United States, separation requirements are imposed on businesses, such as sex shops, that can have recourse to freedom of speech or other constitutional protections (Valverde 2005). And in the United States, because of the particular scrutiny that attaches to racialized forms of spatial segregation, some decisions taken in land use law (which is a great depository of police powers) may be countered by recourse to the Fair Housing Act or other tools of 'high' law (droit de justice). But the sites of conflict are few, even in the US. Sex shops and strip bars might be able to cloak themselves in the First Amendment to challenge some highly discriminatory municipal regulations, while public housing, due to its specific racial composition, can sometimes be forcibly imposed on 'land uses' that are built to be exclusionary. But if a municipality decides to ban hair salons or bars, to prohibit street vending or street music, or to prevent homeowners in certain districts from enlarging their homes or painting them in their favourite colour, there is little or no legal recourse.

Even in highly constitutionalized regimes, it has remained possible for municipalities to micromanage space, time, and activities through police regulations that infringe both on constitutional rights and private property rights in often extreme ways. Throughout North America, municipalities can order people to put their trash out only at certain times and in certain containers; they can demand that citizens clear the sidewalk abutting their property of snow and ice; they can regulate the playing of music on private property and the appearance of buildings; they can impose severe limits on how one can improve or fix one's private home; and so forth. And in the enforcement of these multifarious and haphazardly drawn regulations, a great deal of discretion is necessarily exercised. Legal principles are notable by their absence.

If the police power of the state can take such draconian forms, and this can survive constitutional challenges, it is because, as William Novak influentially argued, police power is another name for the state's concern for the wellbeing of the community as a whole - the salus populi, which has historically included moral as well as physical welfare (Novak 1996). Since what is and is not conducive to moral and physical welfare cannot necessarily be defined in advance, but must rather be decided upon in concrete cases using the discretion that as has been noted above is an inherent part of police powers and police knowledges, police regulation cannot be contained by or in legal principles of general application. But the question Novak's work does not answer is: what made it possible for the salus populi logic to survive, and even to thrive (as anti-homeless ordinances demonstrate (Feldman 2004), despite the obvious contradiction between the logic of police power and the better known liberal logic of national citizenship? The answer, I suggest, is that police power typically works at the local scale (as a search of 'police power of the state' cases in US law quickly demonstrates). Citizenship and constitutional rights, by contrast, are rarely visible locally: they exist mainly on another map drawn at a different scale. The shift in scale from droit de police to droit de justice facilitates this coexistence of conflicting legal orders. 
Having established the basic outlines of the typically local forms of power/knowledge that huddle under the banner of police, and shown how scale works to separate local police work from state-level law work, such that structural conflicts are rendered largely invisible, let us now return to the question of whether the game of the division of powers that scale enables could perhaps be better understood if in addition to the geographical notion of 'scale' we also drew on the resources of practices of jurisdiction.

\section{Is 'the local' a scale? The tyranny of cartographical thinking}

In the past ten or twenty years it has become fashionable among social theorists to decry 'historicist' thinking and to promote instead the virtues of spatial analysis Lefebvre (1991) is often cited as inspiration, although it is not clear that Lefebvre would have wanted spatialization to be used as a hammer to beat historical analysis with). Within critical socio-legal studies in particular, 'law and space' has much more cachet, as a subfield, than the historical analysis of legal techniques. In keeping with this trend, scholars interested not in actual spaces but in problems of social relations have borrowed a number of analytical tools from geography, and more specifically from cartography.

I must emphasize that I am by no means criticizing the borrowing of geographical concepts and metaphors as such; questions of space, or of relations that can be imagined as if they were spatialized, are in fact central to studies of law and security, and so the engagement of socio-legal studies with geography and quasi-geographical studies is a positive development. My point is simply that as is often the case with fashionable conceptual tools, cartographical terms and metaphors are being over-used, or used to explain far too much.

Richard T. Ford, for example, who has pioneered the subfield known as 'law and space' in his analyses of race, jurisdiction, and territoriality, falls into geographical, or more specifically cartographical, determinism, when he writes: "Once cartography made the production of precisely demarcated legal territories possible, territorial relationships quickly became dominant. The territorialization of social relations served important institutional purposes more effectively than did the older status relationships ... Jurisdictions define both national and sub-national territories." (Ford 1999, 845).

Ford is of course aware of the fact that 'jurisdiction' cannot be reduced to territorial divisions. Indeed, in the rest of his influential article, he talks about jurisdiction more as a question of mechanisms to legitimate the use of state power than as a matter of lines on the ground. And in keeping with his concern for the power moves enabled by jurisdiction as such, he emphasizes - as against the conventional liberal zero-sum view of jurisdiction, and power more generally - that local jurisdiction can grow and has grown even as central authorities have multiplied their specific powers. However, this comment, whose implications would undermine Ford's privileging of the technical features of cartography - since in cartography the use of one scale or map projection necessarily negates other possible scales or projections - is not followed up in the conclusion.

Ford's subtle and original analysis - which remains today the only substantial effort to theorize local jurisdiction, from the law-and-geography perspective - is flawed by his initial assumption that the science of cartography was the key precondition for the territorialization of jurisdiction. And it is further flawed by the fact that he cannot begin to prove that jurisdiction has in fact become increasingly territorial. As Ford's own remark about the simultaneous growth of powers at both local and central levels would suggest, the decline of certain status-based legal obligations (e.g. master-servant law) by no means 
implies that territorial divisions, in general, have become more important. I suspect that it would not be difficult to prove, by means of counter-examples, that

(a) jurisdiction is only territorialized in certain limited situations, especially in federal states; and

(b) insofar as jurisdiction may have become more territorially based in recent centuries - and no comprehensive study could be devised to test this hypothesis, given the rise of complex new jurisdictions in private law - the influence of cartography is only one among many factors at work.

Re-reading Ford's article some years after the initial enthusiasm for borrowing from critical geography can help us to begin to question the routine assumption made in the urban studies literature that 'the local' can be identified as a scale - a scale smaller than that used to visualize 'the national' but larger than that used to talk about, or on behalf of, 'the neighbourhood'.

A feature of the landscape that is invisible in any national-level map but is visible in city maps can be described as 'local'. Even at the level of actual (as opposed to metaphorical) geography, scale is by no means ideologically neutral: the conventions that lead map makers to show railways and highways, but not individual buildings, however large, on national-level maps are by no means 'neutral'. Nevertheless, if one were to grant that it would be technically very difficult to show Toronto City Hall on a national or even provincial map, due to problems of scale, it may not be particularly helpful to assume that Toronto's garbage disposal problem belongs, for technical reasons, to a local jurisdiction.

The distinction between local garbage collection and national immigration control is not merely a matter of scale in the cartographic sense. As the discussion of the police power and droit de police showed, there are important qualitative differences distinguishing largely local police-style powers and knowledges from the largely (though not invariably) national-level powers and knowledges that generally 'see like a state'. When adjudicating questions of jurisdiction, appellate courts usually focus on who governs what: but their decisions also end up determining how governance happens - something which is by no means a secret, but which has rarely been theorized.

Appellate courts (and other courts dealing both with jurisdiction cases and with what US law calls 'conflicts of laws') tend to blackbox the 'how' of governance because the questions they are obliged to answer are mainly about 'who' governs. Nevertheless, questions about 'how' are often mentioned, and are sometimes even at the centre of the case. ${ }^{3}$

2 In legal studies neighbourhoods tend to be invisible, but in fact numerous legal mechanisms exist that render neighbourhood relations visible and actionable. The most obvious examples are boroughs (as they exist in New York and in London). A fuller study of the question of the relation between jurisdiction and scale of governance would have to include the neighbourhood as a distinct level; and, in keeping with the earlier analysis of how police regulation is qualitatively distinct from state law, my (not yet published) research on neighbourhood-level conflicts in Toronto shows that the micro-local too cannot be reduced to a geographic location: I have found that successfully assuming the role of speaking for 'the neighbourhood' is as much a matter of status as of postal address.

3 An example from Canadian Supreme Court jurisprudence is a constitutional challenge, by a gay bookstore, to the censorship practices of Canada Customs officials (Little Sisters v. Minister of National Revenue). That police officers enforcing obscenity statutes could never have engaged in the kind of censorship that Canada Customs carried out was very obvious to everyone, including the court, and this sharp conflict in governing logics, though not explicitly featured, fuelled the lively arguments between the majority and the minority judges about the role of courts in the governance of administrative policies. 
This means that if we want to think critically about how it was that we came to assume that garbage disposal is local but railways are national, if we want to think about how security at the local level differs, qualitatively, from security at the national level, we may find that black letter law has resources that have been largely ignored by critical law and geography.

What such an analysis would find is at this point not yet clear, since the only example that has been examined in this article (typically local police regulations) does not allow generalizations about the workings of jurisdiction as such. But it is clear that appellate courts' knowledge work should be closely scrutinized, since they are officially in charge of resolving the infrequent conflicts that arise when jurisdiction is uncertain or when someone makes an effort to have a problem habitually managed at one scale by one kind of authority be re-assigned to a different type of law. As Annelise Riles has recently put it, analyses of legal processes that only look at extra-legal relations of social power run the risk of reducing legal artefacts to invisibility or irrelevance, as if how power and knowledge work through law did not matter once one has identified in general terms the character of such powers and knowledges (Riles 2005, 979-981). The Bourdieuists reduce legal machines to mere vehicles for the exercise of existing cultural and economic capital, the feminists reduce law to an instance of the same masculine power one finds everywhere else, and so forth. In order to avoid sociological reductionism, and in order to better understand the 'how' of legal mechanisms, analyses need to be simultaneously inside and outside law, simultaneously technical and theoretical, legal and socio-legal. Doctrinal 'technicalities' (the doctrine of ultra vires; constitutional documents about jurisdiction, rules for allocating jurisdiction or forcing government officials to occupy and use their jurisdiction) would be as important in such a study as sociological analyses of power effects carried out either through structural analyses or through interviews with complainants, legal actors, and advocates.

And yet a purely legal study of 'technicalities' would not suffice. Any critical study of the question of how existing divisions of knowledges and powers are produced and reproduced in 'technicalities' such as those that huddle under the legal umbrella of jurisdiction would have to begin by studying how claims that seek to upset the system came to be made in the first place. So in addition to closely analyzing the work done by legal machineries such as 'jurisdiction', one would have to ask extra-legal questions, such as: how did the party that decided to launch, say, a constitutional challenge against a city by-law, imagine the space of their dispute? What kind of knowledges did they think would further their effort to remove an issue from one level/jurisdiction and locate it elsewhere in the governmental system? How did existing spatial imaginaries in turn shape the choice of legal venues and avenues? (cf. Cooper 1998)

Maintaining this dual methodology, one that takes 'technicalities' to be as important as the social relations of power within which law governs, could have salutory theoretical effects. Specifically, following up on the observations made here about jurisdiction, scale, and the governance of security we may, along the way, begin to deconstruct the law and society movement's founding binary, which is that of law in the books vs. law in action.

Law in the books, as the above remarks on jurisdiction show, is also law in action. Jurisdiction's work is not reducible to territorialization, or to scale - and in general, no one set of analytical tools drawn from some other field of governance can be expected to fully explain the workings of a different field. The actual machinery of jurisdiction is far too complex to be adequately analyzed by reference to two-dimensional cartographical exercises, or even by the tools of critical geography more generally. But by the same token, a 
merely technical analysis - such as those produced by appellate courts engaging in the work of allocating jurisdiction or policing its exercise - tends to reduce conflicts among competing powers/knowledges to a classificatory exercise of deciding what governing activity belongs in what drawer, a sorting process that obscures the incommensurabilities and the conflicts that see the under the surface in the most mundane of jurisdiction cases.

A full study of the workings of jurisdiction is clearly beyond the scope of this short and largely preliminary article, but the brief discussion of the local gaze of the police power carried out above may perhaps serve as an example of the kind of combined legal and socio-legal analysis that could help us to better understand how we govern ourselves through legal machineries that, like many other human-made tools, are more complex than most of their users realize.

\section{References}

Blomley, N. (1994) Law, space, and the geographies of power. New York: The Guilford Press.

Blomley, N./Bakan J. (1992) Spacing out: towards a critical geography of law. In: Osgoode Hall Law Journal, Vol. 30, no 3: 661-690.

Blomley, N./Delaney D./Ford, R., eds. (2001) The legal geographies reader. Oxford University Press.

Cooper, D. (1998) Governing out of order: space, law, and the politics of belonging. London: Rivers Oram Press.

de Sousa Santos, B. (1987) Law: a map of misreading. Toward a postmodern conception of law. In: Journal of Law and Society, Vol. 14, no. 3: 279-302.

Dubber, M. (2005) The police power: patriarchy and the foundations of American government. New York: Columbia University Press.

Dubber, M./Valverde, M., eds. (2006) The new police science: the police power in domestic and international governance. Stanford University Press.

Dubber, M./Valverde, M., eds. (2008) Police and the liberal state. Stanford University Press.

Duneier, M. (1999) Sidewalk. New York: Strauss, Farrar and Giroux.

Espeland, W. (1998) The struggle for water: politics, rationality and identity in the American southwest. University of Chicago Press.

Feldman, L. (2004) Citizens without shelter: homelessness, democracy, and political exclusion. Ithaca: Cornell University Press.

Ford, R. (1999) Law's territory: a history of jurisdiction. In: Michigan Law Review, Vol. 97, no. 4: 843-930.

Foucault, M. (1979) Discipline and punish: the birth of the prison. New York: Vintage.

Foucault, M. (2005) Securité, territoire, population. Paris: Gallimard.

Hawkins, K. (2002) Law as a last resort: prosecution decision making in a regulatory agency. Oxford University Press.

Hunt, A. (1996) The governance of the consuming passions. Cambridge University Press.

Lefebvre, H. (1991) The production of space. Oxford: Blackwell.

Levi, R./Valverde M. (2001) Knowledge on tap: police science and common knowledge in the legal regulation of drunkenness. In: Law and Social Inquiry, Vol. 26, no. 4: 819846.

Loader, I. (2007) Civilizing security. Oxford University Press. 
Mitchell, T. (2002) Rule of experts: Egypt, techno-politics, modernity. Berkeley: University of California Press.

Napoli, P. (2003) Naissance de la police: pouvoir, normes, societé. Paris, La Découverte.

Novak, W. (1996) The people's welfare: law and regulation in nineteenth-century America. Durham NC: University of North Carolina Press.

Poovey, M. (1998) The making of the modern fact: problems of knowledge in the sciences of wealth and society. University of Chicago Press.

Riles, A. (2005) A new agenda for the cultural study of law: taking on the technicalities. In: Buffalo Law Review, Vol. 53: 973-1023.

Scott, J. (1998) Seeing like a state. New Haven, CT: Yale University Press.

Simon, J. (2007) Governing through crime. New York: Oxford University Press.

Smith, A. (1896 [1763]) Lectures on jurisprudence, police, revenue, and arms. Oxford: Clarendon.

Valverde, M. (2005) Authorizing: appellate courts and their knowledge games. In: Law and Society Review, Vol. 39, no. 2: 419-456.

Valverde, M. (2007) Genealogies of the modern state: Foucaultian reflections. In: Economy and Society, Vol. 36, no. 1: 412-138.

Wood, J. (2007) Imagining security. Philadelphia: Temple University Press.

Young, I. M. (2002) Inclusion and democracy. New York: Oxford University Press.

Zukin, S. (1988) Loft living: culture and capital in urban change. London: Radius.

Trained originally in political theory, Mariana Valverde has been working in the sociology of law for over a decade now. Some key works include: Diseases of the will: alcohol and the dilemmas of freedom (Cambridge, 1998) and Law's dream of a common knowledge (Princeton, 2003). Her current research focuses on the governance of urban order. E-mail:m.valverde@utoronto.ca 